\title{
Rock Art and (Re)Production of Narratives: A Cassowary Bone Dagger Stencil Perspective from Auwim, East Sepik, Papua New Guinea
}

\section{Roxanne Tsang $\odot$, Sebastien Katuk, Sally K. May ๑, Paul S.C. Taçon $\odot$, François-Xavier Ricaut \& Matthew G. Leavesley}

\begin{abstract}
Cassowaries (Casuarius) are one of the largest indigenous animal species of New Guinea. Researchers have long been trying to understand their local socio-cultural significance. Here we present new results from interviews recorded in 2018 on ethnography associated with bone daggers, a material culture ornament and tool carved from the cassowary's tibiotarsus. We present a 'storied notion' - a contemporary narrative from oral history of why cassowary is not simply a bird, and briefly describe cassowary bone ornamentation in Auwim, East Sepik Province of Papua New Guinea. By exploring the material history of Casuarius through a 'storied notion' approach, we reveal that cassowary bone daggers in rock art are narrative ideas of the species from its landscape to ornamentation and through to people's cosmological beliefs surrounding Casuarius. We argue that the cassowary bone dagger stencil can be seen as part of the life history of this animal.
\end{abstract}

\section{Introduction}

Stencilled objects in rock art are widespread in Australia, the Asia-Pacific, including Papua New Guinea (PNG) and many other parts of the world. Objects made from animal body parts provide valuable information on how people perceive and categorize their human-animal world. They also give us an idea of how animals are constituted or reconstituted in specific places and cultures that differ from place to place and from culture to culture. Even more unique are stencils of those animals that are indigenous to specific parts of the region or world. In Australia, such animal stencils include ancient bird stencils (Taçon et al. 2010-see also for a summary of stencils in Australia), but there is also a wide range of material culture object stencils (Hayward et al. 2018), as in other parts of the world (e.g. Bahn 1998). In PNG, stencilled objects provide a unique opportunity to understand better not only the technological aspect of the material culture, but also their place within cultural belief systems. Such stencils include shell ornaments (e.g. kina, baler, conidae-shape-like stencils), and human and animal body-parts (e.g. hand stencils, hand-and-arm stencils and foot stencils; bone dagger stencils and bird foot stencils) (Edwards \& Sullivan 2008; Gabriel \& Gorecki 2014; Gorecki \& Jones 1987a,b; Tsang et al. 2020; 2021). Our fieldwork in 2018 within the Upper Karawari-Arafundi region of PNG highlighted yet another key object stencil—the cassowary bone dagger. However, the implications of stencilling 'real' objects and capturing them in 'paintings' either represent the end of that animal's life history or a point of regeneration or reproduction.

A cassowary is a ratite and therefore closely related to an ostrich, emu or moa. At a young age, cassowaries have brown thin feathery plumage with a plain brown head (Fig. 1), but an adult has black wispy plumage with a garishly coloured head 


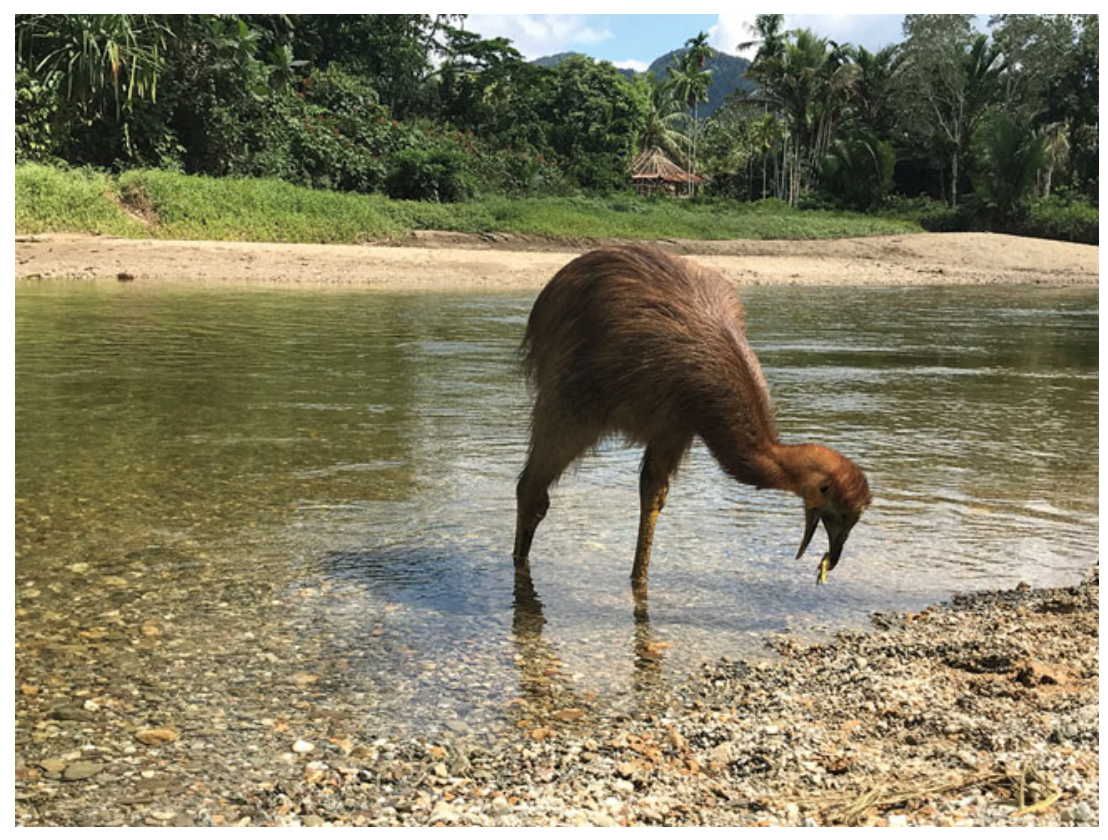

Figure 1. A juvenile C. unappendiculatus named Tukana in Endum Creek, Auwim, East Sepik, Papua New Guinea, 2018. (Photograph: Roxanne Tsang.) crowned by a bone casque with a long single wattle (Newton 1989, 305; fig. 4) (Fig. 2). There are three main species: Casuarius unappendiculatus, Casuarius bennetti and Casuarius casuarius. All species are found within the broader New Guinea region, comprising the current Indonesian political boundaries of West Papua and Papua, and PNG (Fig. 3). Some of these species also inhabit Raja Ampat and Seram Islands including New Britain (in the Bismarck Archipelago) and northern Australia. C. bennetti on New Britain is not endemic and is considered a human-assisted translocation, but the introduction date is uncertain (Steadman 2006, 130-31, cf. cited in Specht et al. 2021, 204).

In this study, our focus is C. unappendiculatus as it commonly occupies the East Sepik Province of PNG, the geographic emphasis of our research (Newton 1989). Indeed, it is an endemic species of the lowland regions of northern New Guinea, hence its prevalence in the forest swamps of the East Sepik region. Often referred to as the northern cassowary, it has a height of between 150 and 180 $\mathrm{cm}$ and a weight range of $25-60 \mathrm{~kg}$, owing to sexual dimorphism (Pangau-Adam et al. 2015). As frugivores, they are highly dependent on forest seeds and often live near water source areas. PangauAdam et al. (2015) suggest five main habitation areas of the northern cassowary: primary forests, forest gardens, hunted natural forest, secondary forest and logged areas. The first of these areas is the most prominent, given its high canopy cover (PangauAdam et al. 2015, 737). Although their data do not include east New Guinea, we believe these habitation areas are equally similar to the East Sepik region.

Cassowaries are not only an economic resource for local people, but they also play a key role in cultural belief systems. Since 1967, researchers have provided evidence for cassowaries featuring in local cultural narratives (e.g. Bulmer 1967; Gardner 1984). Others have noted the importance of bone daggers made from cassowary bone and their use as personal ornaments (e.g. Dominy et al. 2018; Newton 1989). In the case of cassowary bone daggers, they do not just 'represent' or 'stand in place for' but actively help to manifest and tell these narratives. The rearing and killing of cassowaries and recycling of bones for tool making, and then the production of rock-art stencils from these tools, are actually the activities that shape people's classification schemes (for instance, for the Karam and Mianmin people, cassowaries are not considered as birds: see e.g. Bulmer 1967; Gardner 1984), hierarchies of value (cassowaries are often prestigious birds to hunt owing to their scarcity and ferocity: e.g. Bulmer 1967; Pouwer 1991), and so on. These are peoples' ways of making sense of the world, ways of actually creating 'narratives' about the world, ways of storying the world. Therefore, the cassowary dagger stencilling is part of the life history of the cassowary. The stencils do not just reflect the history of the cassowary, but the production of these stencils may have been a real and perhaps integral activity that carried forward the cassowary life history in Auwim society. 
Figure 2. Adult cassowary, C. unappendiculatus. (Photograph: https://commons.wikimedia.org/wiki/ File:Casuarius_unappendiculatus_qtl1. jpg)

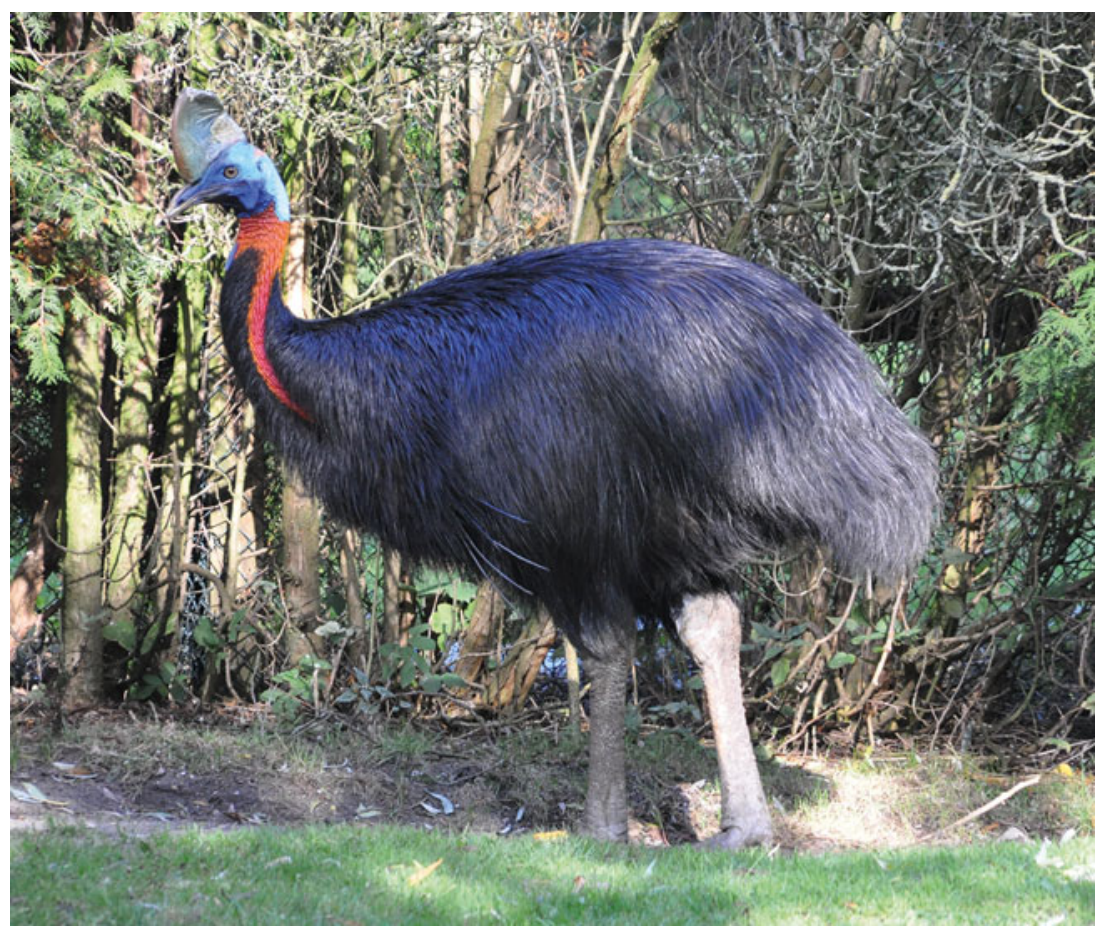

Using field interviews recorded during fieldwork in 2018, we build upon previous research by presenting new archaeological and ethnographic evidence for cassowary bone daggers appearing in rock art from Auwim in the Upper Karawari-Arafundi region of East Sepik. We begin by providing an overview of cassowary bones and their daggers in both the archaeological and ethnographic context. Then we describe and discuss how local knowledge can help us to interpret better the significance of the stencilled bone daggers in the rock art of PNG through a 'storied notion' approach-contemporary narratives from oral history conversational interviews with current community elders (i.e. cultural understanding through ethnohistory). Our understanding is that these narratives do not necessarily recount the original 'meaning' inscribed into the rock art, but continue to evolve, as new narratives emerge. Our primary interest is exploring the social, cultural and economic role of cassowary and, specifically, cassowary bone daggers as well as their cultural significance and deliberate placement within the rock-art assemblage of this region.

\section{The archaeology of cassowary bones in New Guinea}

Archaeologically, the presence of cassowary bones is very sparse throughout New Guinea. In West Papua, cassowary eggshells, bones and possible artefacts are found in both Toé and Kria caves (Pasveer 2004) including several Maluku sites ( $\mathrm{O}^{\prime}$ Connor et al. 2005). While we have yet to uncover cassowary bones in the archaeological context in East Sepik, partly due to a lack of research, to its west, bones have been reported from Lachitu (O'Connor et al. 2011). In the montane region, cassowary bones, bone tools and eggshells have been recovered from Kiowa (Bulmer 1964; Denham 2016; Gaffney et al. 2021), Aibura (White 1972) and Nombe (Denham \& Mountain 2016; Gaffney et al. 2021; Mountain 1991; White 1972), bones at Kamapuk (Aplin 1981; Christiansen 1975) and eggshells at Yuku (Bulmer 1975; Denham 2016; Gaffney et al. 2021), Kafiavana and Batari (White 1972). Further south in the Gulf, several sites containing bones have been reported (Rhoads 1980). In the Central Province, bones have also been reported from Oposisi and Urourina (Vanderwal 1973), Nebira (Bulmer 1979) and within the Bootless Bay area (Allen 2017, 35). Most recently, research revealed that cassowary eggshells at Yuku $(17,500$ years old) are earlier than Kiowa (dated to 12,000 years ago), and eggshells at Toé cave are the earliest direct evidence dating to the Last Glacial Maximum for the exploitation of cassowary nests (Gaffney et al. 2021). Furthermore, recent analysis into cassowary eggshell microstructural variation from the Highlands region has revealed a distinct pattern of harvesting eggs which may reflect human dietary preferences and hunting seasonality 


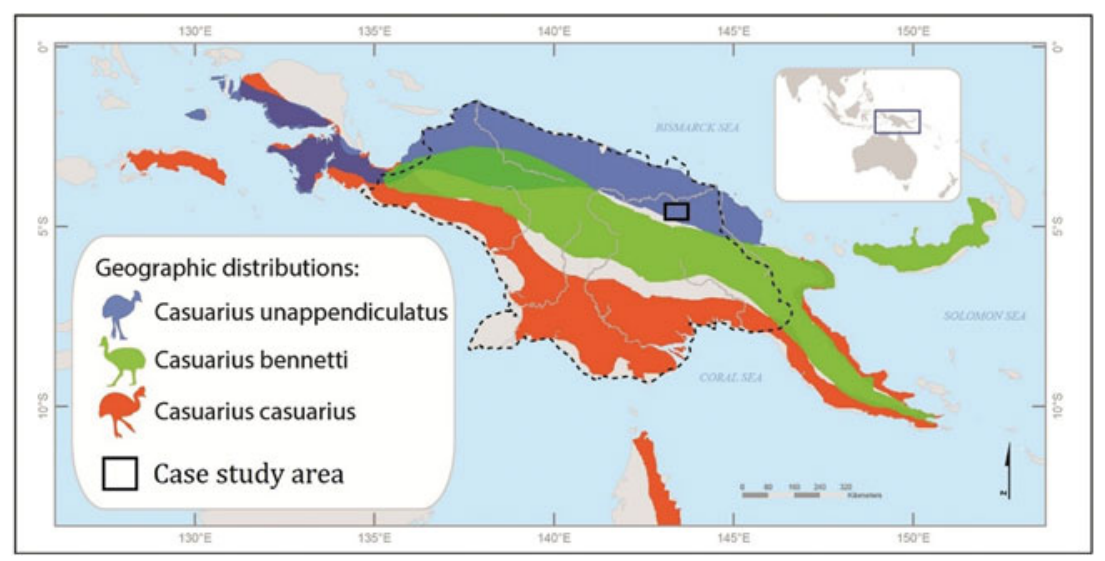

Figure 3. Map showing the distribution of cassowary. (Adapted with permission from Dominy et al. 2018, 4, fig. 5.)
(Douglass et al. 2021). Altogether, these sites show evidence of human-cassowary interactions from the Late Pleistocene to Holocene (Douglass et al. 2021, 50-53) which could possibly suggest their bones have also been worked into tools.

\section{Cassowary bone daggers}

Cassowary bone daggers are often made out of the tibiotarsus. These daggers' diagnostic features have been described by various scholars (e.g. Dominy et al. 2018; Newton 1989). Typically, 'the Sepik cassowary bone dagger has no separate or demarcated grip and no guards'; indeed, it is the length of the actual tibiotarsus bone (Newton 1989, 307). The average length is about $30 \mathrm{~cm}$ and its widest is $3 \mathrm{~cm}$ (Fig. 4; see also Newton 1989, 307). As these objects' intended purpose is weaponry, they are often sharpened at the edge or shaped into a needlepoint at the proximal point of the object. As can be seen in Figure 5, the Auwim cassowary daggers recorded in 2018 are simple, with a smooth surface and with no abstract designs. There might have been earlier specimens with intricate designs, but this has not yet been established from the current local informants and/or museums around the globe. However, Newton $(1989,308,312,319)$ has identified and collated various bone dagger types with designs from other areas of East Sepik.

Newton's (1989) work focused on the bone daggers of the coastal and inland plains of East Sepik and their distribution in space associated with language, including their mythological and cultural aspects. He highlighted that they are prevalent near the border in West Sepik and the Ramu River areas (Newton 1989, 307). However, he also mentions that they are common in inland East Sepik, but this is as yet under researched. Recently, Dominy et al. (2018) analysed bone daggers (both human femur and cassowary tibia) from museum collections. They used computed tomography to scan each specimen collected from the early-mid twentieth century, measured the properties of modern cassowary bones, and then compared their results. Their results suggest 'that people in the Sepik region ... engineered human bone daggers to withstand breakage, and that their prevailing motivation was to preserve intact the embodiment of symbolic strength and social prestige' which concurs with 'signalling theory' (Dominy et al. 2018, 10). In this context, the human dagger seems to be more powerful considering that 'emi bun bilong yumi [it is our bones]', implying that these are their ancestors' bones and, thereby, give them more strength in combat including tribal warfare (Newton 1989, 306).

Cassowary bone daggers are very sparse archaeologically, which may generally relate to the tropical environment conditions in New Guinea (see e.g. Basiaco et al. 2020) and/or lack of research. The absence of bone daggers could also relate to their being valued and therefore not so readily discarded. At Nombe, White (1972) briefly reported bone artefacts from his 1964 excavations. Forty-six pieces of worked bone were recovered. Strikingly similar in shape to the current bone daggers from East Sepik are what White (1972, 134-5, figs. 24b, c, \& f) describes as 'awls' and the 'broad flat point'. Six awls of $6.3-8.3 \mathrm{~cm}$ long are made from bird or bat long bone, which is rather smaller (in size) than the recently carved daggers. Locals associated the awls with tools for making armlets and orchid fibre, while the 11 broad flat points were considered to be made from splitting sections of long bone. White $(1972,134-5)$ indicated that they are probably made from macropod or cassowary bones, although the specimens were fragmented. He cautiously speculated that awls seem to be more recent as 
they are found near the surface. The broad flat points correspond to Kiowa jabbers (Bulmer 1966, 102, 106, cited in White 1972,134), which are commonly found in the lower horizon at Nombe. He argued that the lower horizons of Nombe generally correspond to Kiowa levels 4-8, while the tools in the upper part of Nombe are similar to those of Kiowa levels 1-2, which are older than about 5000 years BP (White $1972,135)$. White also speculated that Nombe postdates Kiowa and cassowaries were rarer before, or the absence of cassowary bones at Nombe might relate to different site use (Bulmer 1966; White 1972, 130). This suggests the possible use of bird bone daggers from 5000 years ago, albeit much smaller in size. Yet the Nombe chronology, in association with the possible cassowary knives from White's work, remained very tentative until Mountain's (1991) research. Furthermore, recent work has established that the Kiowa site is more reliable and suggests cassowary bone artefacts, including 'jabbers', were in production from 9000-1000 years ago (Gaffney et al. 2021). At Kiowa, 57 per cent of the specimens have been identified to be of Casuarius tibiotarsi, while another 14 per cent are femurs and a further 14 per cent are tarsometatarsi (Gaffney et al. 2021, 9). Gaffney and colleagues mentioned that tibiotarsus may have been chosen because of the amount of meat perhaps for people's subsistence diet. We speculate instead that it could relate to the extracting of raw materials for post-dietary tool manufacture. However, use-wear analysis would be required to distinguish if they are borers, daggers, or something else. Moreover, while tentative, bone daggers could be a Late Holocene innovation, but further research is needed.

\section{The ethnography of cassowary bone daggers}

Cassowary bone daggers are rarely discussed in the ethnographic records. For those areas with some ethnographic data, bone daggers have only been mentioned or briefly described. These brief ethnographic reports show varying use of cassowary bone daggers, which reflects their representation following specific cultural norms that differ from place to place. Along the northeast coast of PNG (Vanimo to Madang), a tentative study of 150 bone dagger samples indicated that they were made out of the distal portion of the cassowary's tibiotarsus and rarely traded (Terrell \& Welsch 1990). In the Telefomin region of West Sepik, cassowary bones are utilized for other purposes. For example, the round end of the cassowary femur is used as a chisel for wood carving. Their quills are used as

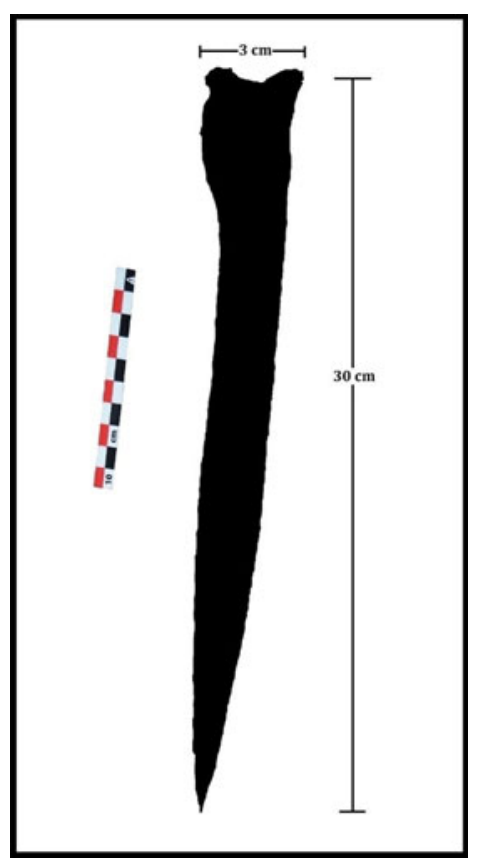

Figure 4. A digital tracing showing estimated measurements of the cassowary bone dagger from Pundimbung site. (Original photograph: Hubert Forestier, Papuan Past Project. Digital drawing and reproduction by Roxanne Tsang.)

decorations, bone gouges are used for carving softwood and preparing the Marita pandanus fruit, and its breast-bone has been observed to hold red ochre (Cranstone 1971, 136, 140). Further south in the Papuan Gulf, ethnographic reports from the twentieth century indicated the use of bone daggers as weapons between 1910 and 1912 (Dominy et al. 2018, 3; Landtman 1933); however, it is not known what these weapons were made out of. Others have reported that cassowary long-bone daggers were used to slaughter pigs for important social and ceremonial occasions (Williams 1940, 319, cited in Basiaco et al. 2020, 226-7, 229, table 1).

Various narratives and cultural beliefs associated with cassowaries have been reported. For example, narratives have been recorded from the Karam (also spelt Kalam) of the inland Madang region (Bulmer 1967; Pouwer 1991), the Mianmin of inland West Sepik (Gardner 1984), the Sambia of East Highlands (Herdt 1981), the Goodenough Island in Milne Bay (Ker 1910) and the coastal mountains and inland plains of the East Sepik region (Newton 1989). It is worth describing Ralph Bulmer's (1967) first-ever record of the ethnotaxonomic features of cassowary which inspired later researchers. For the Karam-language-speaking 


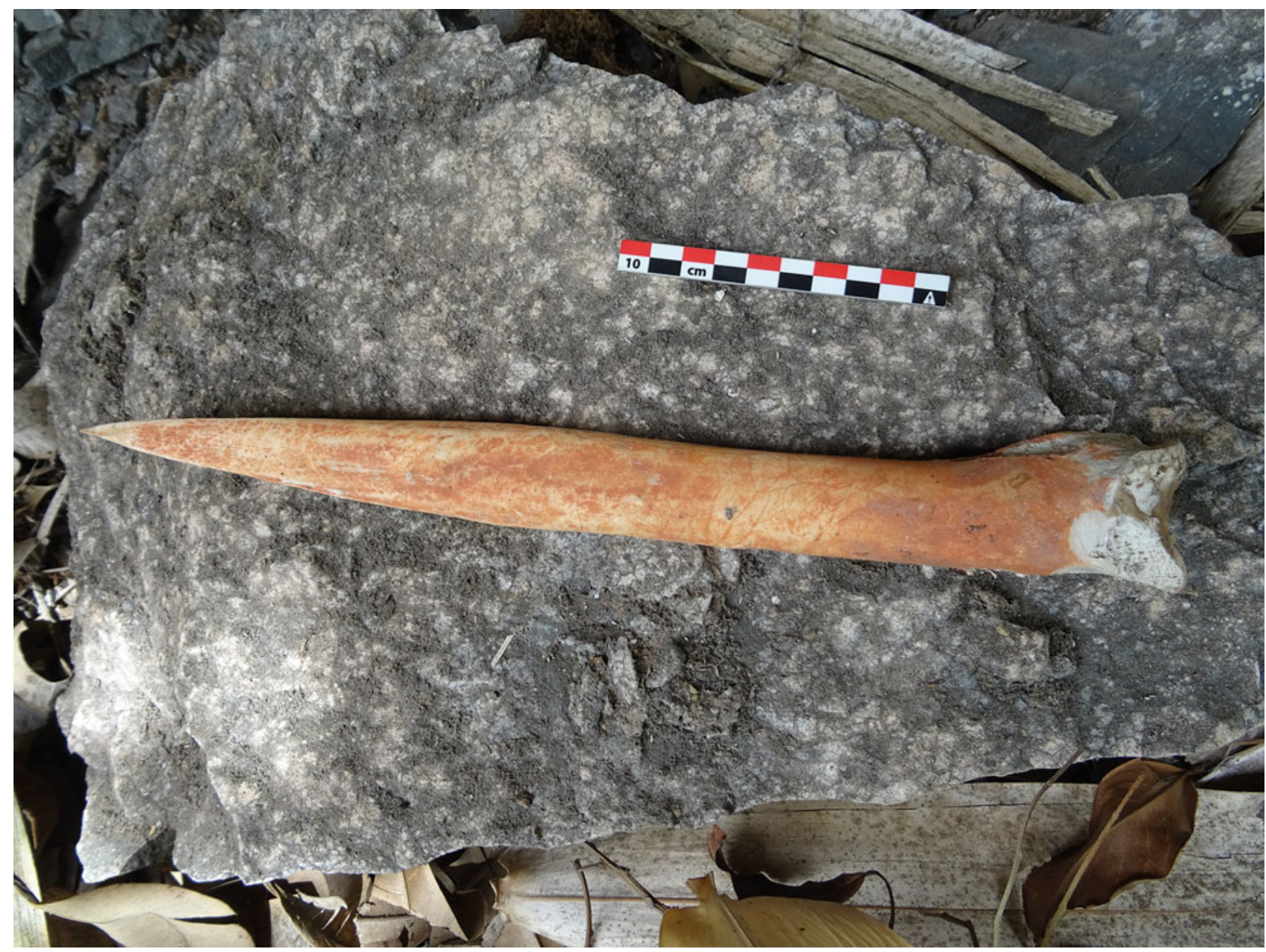

Figure 5. A cassowary bone dagger object at Pundimbung rock shelter in 2018. (Photograph: Hubert Forestier, Papuan Past Project.)

horticulturalist group in the Upper Kaironk Valley, cassowary is not considered a bird as it is their crosscousin. The zoological taxonomy is discriminated into two main groups: 'primary taxa' and 'terminal taxa'. These taxa are determined from the cultural perspective which has little correspondence to either zoology or western concepts of taxonomy. To analyse the Karam taxonomy of cassowaries, Bulmer $(1967,8)$ focused on some logical categories: first, gross morphological similarities and differences (e. g. winged versus wingless) and second, the habitat (e.g. terrestrial and 'of the forest'). Bulmer $(1967,9)$ 'show[ed] that it is not so much wrong as inadequate for indicating significance which certain of these animals have in Karam thought'.

He went on to describe the 'physical' and 'biological' differences between cassowaries and other birds, and bats. Cassowaries are flightless, wingless, terrestrial, larger than other birds, and have heavy, strong and very human-like leg bones, whereas Karam emphasize that they have 'hair' and their 'head is all bone, with no brain'. The other five morphological characters are size, absence of wings, heavy human-like leg-bones and unique pelage and cranial structure. Bulmer elaborated that, to understand why cassowaries receive special taxonomy for the Karam, we ought to understand their relationship to humans (i.e. how, when and by whom they are hunted, how they are used, and how their hunting and utilization are regulated) (Bulmer 1967, 11). In Mount Hagen, where cassowary is common, hunting is carried out by a lot of people, and they either snare, stalk or capture chicks for semi-domestication (Bulmer 1976, 11). However, the Karam had to follow rules and prohibitions to hunt cassowaries because these are very scarce ecologically (see also Bulmer 1976).

Six rules govern cassowary hunting for the Karam. These include practice avoidance relating to 
language used during hunting; cassowary blood must not be shed, which means they are captured through snares, or despatched with techniques using blunt weapons; the hunter or killer is obligated to eat its heart; those who killed/ate the cassowary are in ritual danger; cassowaries should be cooked and eaten in forests and should not be brought to settlements or near taro gardens; and lastly, live cassowaries must not be brought into homesteads and gardens as pigs, banana and taro gardens will not flourish and such birds could not be domesticated (Bulmer 1967, 12). Other restrictions include that only two men can hunt cassowaries, and community members are prevented from eating cassowaries during taro-planting season and several months after while crops are growing and need tending (Bulmer 1967, 12), as taro is a ceremonial crop for the Karam (for more details, see Bulmer 1967, 12-14). Thus, 'cassowary is equated with a man' (Bulmer 1967, 17). They are considered 'cross-cousins (i.e. father's sister's children) and their descendants to men' (Bulmer 1967, 18). Cassowaries' special place for the Karam is related to their thinking of between 'forest' and 'cultivation'. Several important strands drawn from this idea are cassowaries' relation to taro, pandanus nuts and seasonal cropping, forest cultivation linked with kinship roles and rights, and relationships between brother-sister and crosscousins (Bulmer 1967, 19). Lastly, while Karam cassowary beliefs isolate cassowaries in several ways, they are equal to other big game animals in the Highlands region (Bulmer 1967, 19).

Later, Gardner (1984) and Pouwer (1991) expanded Bulmer's (1967) work by emphasizing the local knowledge on species taxonomy. The local knowledge is said to differ because of people's secrecy in ritual life and that the cassowary's physical characteristics indicate its importance in local cosmology. As a tribute to Ralph Bulmer, Pouwer (1991) used data from Majnep and Bulmer (1977) on cassowaries in Western Highlands compared to those in inland Madang, with an emphasis between domesticated and wild cassowaries reflecting the nature-culture divide.

Other researchers, such as Newton (1989) and Dominy et al. (2018), have focused on specific aspects of the bone daggers from East Sepik. The former emphasized that generally bones are connected with the supernatural world and in this respect are commonly used in communication and enrichment for rituals, and myths surrounding cosmology. Broadly, Newton (1989, 309-10) describes two important versions of East Sepik myths about cosmogony. The story is about two human brothers being the creator of humankind and the hero being a female cassowary. There are two major versions (including sub-versions) of the cassowary creation story. The first involves the transformation between being human and cassowary through the feathers, and the second involves the manifestation of cassowary into humankind (Newton 1989, 309-10). Essentially, this highlights that the cassowary is an important aspect of the Sepik's cosmology expressed through various narratives and that they are the creator of humans and their surroundings. Other parts of New Guinea have a widespread belief of the cassowary being an indigenous creator being (e.g. Lattas 1989).

Ethnographic reports also suggest that cassowaries were hunted for their tibias. The tibiotarsus is carved into a weapon generally known as the bone dagger, although we have yet to determine its traditional name. Indeed, Dominy and colleagues have demonstrated that bone daggers are considered to represent male hunting ability, physical and ritual strength and status (Dominy et al. 2018, 5). Also, in the Upper Karawari-Arafundi region, peacemaking ceremonies include the exchange of cassowary bone daggers, bows and shells, which highlights the value of these portable objects (Dominy et al. 2018, 3; Roscoe \& Telban 2004, 106).

\section{Bone dagger stencils in rock art}

In New Guinea, there is very limited literature on the presence of stencilled objects. For west New Guinea, there is as yet no current evidence of bone dagger imagery in the rock-art assemblage, although other objects such as stone axe, bronze axe and boomerang stencils have been reported (Arifin \& Delanghe 2004; Röder 1959). These stencils are significant as they show that highly valued objects with a lot of labour and skill involved in the production were stencilled on the cliffs/cave walls. Bronze axes were thought to be exotic trade objects from Vietnam, imported in exchange for bird-of-paradise plumes (Swadling et al. 2019, 53-8). Boomerang stencils are prevalent in the Berau Gulf including other parts of West Papua and are similar to those in northern Australian sites (e.g. Arnhem Land) (see Arifin \& Delanghe 2004, 89-91). However, locals in the Berau Gulf no longer use these material objects and as well as there is no available ethnography relating to their use (Arifin \& Delanghe 2004, 90). For east New Guinea, the closest object to boomerang stencils is bone dagger stencils. However, the bone dagger stencils may be much more recent, especially as there is contemporary ethnographic information about them. 
Elsewhere in PNG, cassowary rock art (stencils, paintings or engravings) is quite rare. On Goodenough Island in Milne Bay, some boulders are said to be elements of a cassowary narrative about a woman's anger with her husband about food. The woman transformed into a cassowary and ran into the bush, provoking her husband to throw stones at her (Ker 1910, 90-92, cited in Egloff 1970, 150). The boulders are said to be the cassowary stones, which is an uncommon narrative from this region; however, it is perhaps linked to earlier connections with mainland New Guinea. The only report about rock art from the early twentieth century revealed a painting of cassowary from the Bomana area outside of Port Moresby (Strong 1923), but a detailed description was not undertaken. In New Britain, an engraved drawing of $C$. bennetti among other megapodes recorded in the early 1960s has recently been reported (Specht et al. 2021). From the Upper-Karawari-Arafundi region of East Sepik, six bone dagger stencils were reported in 1987 from one site, Pundimbung (Gorecki \& Jones 1987a, 10; 1987b) but it has yet to be determined how many are of daggers made from human versus cassowary bone.

The Pundimbung site (Fig. 6) is a $60 \mathrm{~m}$ long open overhang (or cave) with cliff edges. The site once functioned as a sacred, ritual and/or ceremonial cave and contains both stencils and paintings. Stencils constitute 97 per cent $(n=562)$ of the motifs with only 3 per cent paintings $(n=18)$. Of these, the stencils include 514 hand and foot motifs (left and right hand, hand, left and right hand+arm+forearm, hand+arm+forearm, left and right foot, foot and finger arrangements), 23 shell ornament motifs (kina and baler shells and shell rings), 11 bone motifs (bone dagger, bone spoon, flying fox bone needle ornament, and turtle bone), five animal body-part motifs (cassowary leg, megapode foot, dog paw + leg), five leaf motifs, three unknown objects and one steel bush knife motif (Gorecki \& Jones 1987a, 10, table 1; 1987b, 10, table 1). Eighteen paintings include three handprints, one kina shell, two cassowary tracks, three complex figures, eight parallel lines and a stain reflecting an indeterminate motif (Gorecki \& Jones 1987a, 10, table 2; 1987b, 10, table 2). The site also contains evidence of superimposition, exfoliation and repainting on hollowed surfaces (Gabriel \& Gorecki 2014; Gorecki \& Jones 1987a,b; Tsang et al. 2020).

Gorecki and Jones $(1987 a, b)$ were told that these sorts of stencils were usually daggers made of cassowary or human bone and that the originals were used in homicide events (Gabriel \& Gorecki 2014,
25). The local informants were not forthcoming with further information. For cassowary bone daggers in rock art, our new results from Auwim in the Upper Karawari-Arafundi region of East Sepik provide further evidence for the cultural context of cassowary bone daggers and their role in rock-art assemblages.

\section{New evidence from Auwim}

In 2018, our team spent two weeks in Auwim, East Sepik (Fig. 6) working with local community members to document rock-art sites and record associated cultural information (Fig. 7). Using informed and formal methods (Taçon \& Chippindale 1998), five sites in total were documented (Apuranga, Akuansam, Kundumbue, Pukan and Pundimbung). Of these, Apuranga and Pundimbung sites contain at least one bone dagger. A total of 12 bone dagger stencils were documented at Pundimbung (Figs. 8-9) and only one plain tibiotarsus or long-bone stencil (possibly human) was recorded from Apuranga. Information on the bone stencil from Apuranga was not collected due to time constraints, but the rock-shelter is similar to Pundimbung in relation to altitude, site orientation and stencil motifs (e.g. the site contains hand stencils, hand-and-arm stencils, foot stencils, material object stencil-i.e. bone and leaf stencils). However, the Apuranga stencils were only made in 2018 and also first recorded archaeologically at this time (see Tsang et al. 2021), whereas Pundimbung was initially reported more than 30 years ago (Gorecki \& Jones (1987a,b).

Following Gorecki and Jones $(1987 a, b)$, who previously identified this object with local assistance, we interpreted the stencilled objects depicted in Figures 8, 9 and 10 as 'cassowary bone daggers'. Forty-two per cent of the daggers $(n=5$; Fig. $8 a-f)$ are located at the beginning of the rock wall (i.e. panels $1-3), 16$ per cent towards the middle $(n=2$; Fig. $8 \mathrm{~g}-\mathrm{h})$ and the other 42 per cent $(\mathrm{n}=5$; Fig. 9ip) in the middle panel of Pundimbung rock-shelter (Fig. 11). Generally, their location across the shelter is sporadic, although panels 1-3 at the entrance of the rock-shelter towards the middle seems to contain more than the others (Fig. 11). This may suggest that these sections of the cave are dedicated to the bone dagger events, which could be linked with men and boy's initiation sections of the rock-shelter, but further fieldwork is required for clarification. Also, measuring each motif specimen could determine if the same bone dagger was stencilled, although this has not been conducted due to Covid-19 travel constraints. However, visually, some bone dagger 


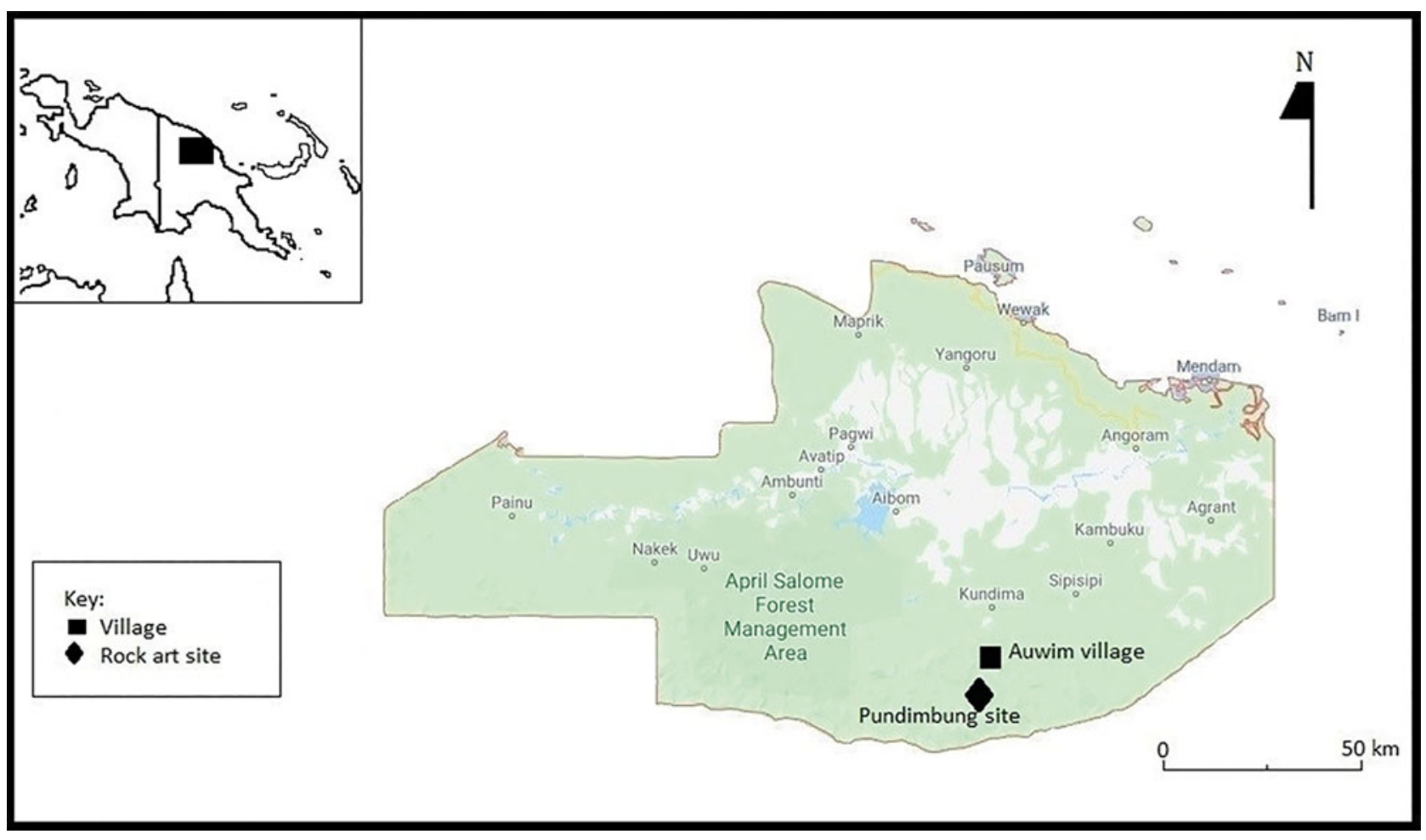

Figure 6. East Sepik, showing locations of sites mentioned in the text. (Adapted from (c) Google Maps by Roxanne Tsang.)

stencils are comparable to an actual dagger found in the rock-shelter at the time of our visit in 2018 (compare Figure 5 with Figure 10), but there are also smaller-sized dagger stencils present (e.g. compare dagger imageries in Fig. 8e-f). The smaller-sized dagger stencils could also possibly represent other megapode or flying fox needle bones as initially identified by Gorecki and Jones (1987a, 10; 1987b, 10). Given the presence of bone dagger ornament and rock-art imageries, interviews were then conducted with local Auwim elders.

On 8 May 2018, through a conversational and open-ended interview, a traditional narrative of the cassowary was collectively told to RT by SK (Fig. 12), Mark and Peter in Melanesian pidgin, the PNG nation-wide lingua franca Tok Pisin, translated into English and written down. The written version of the narrative was read to SK, Mark and Peter for correction and verbally approved by the participants before the finalized version was considered complete. An interpreted version of the narrative by Tsang $(2018,16)$ is as follows:

Prehistorically according to local legends, like other bird species, cassowary (muruk- in Tok Pisin) was a flying bird. During their lifetime on trees, branches kept breaking when they sleep at night because of their size and weight. When these tree branches break, other bird species also complain about losing their nests and food depletion (that is, insects/other small creatures that live on these branches); this made all the birds angry. One day, the entire bird community had a meeting regarding this issue. They then decided that they should throw the big birds such as cassowary down to the ground which means they need a volunteer to do that. The smaller birds were mostly affected; hence, they were assigned to shoot the cassowary so it would fall and never come back up. During the night when the cassowary was fast asleep, the small birds used sticks and shot at the cassowary. It fell to the ground, hurt itself so badly that it never wanted to fly back up. That is why cassowary now lives on the ground and no longer fly.

The narrative as presented above highlights that for cassowary and cassowary bone daggers some information could be shared, as opposed to human tibia and daggers associated with ritual activities and knowledge that is withheld. This reflects a layered knowledge system, because no information about the cassowary origin narrative was disclosed to Gorecki and Jones in 1987.

In Auwim, cassowary husbandry is still maintained today (e.g. Fig. 1). In the nearby Highlands 


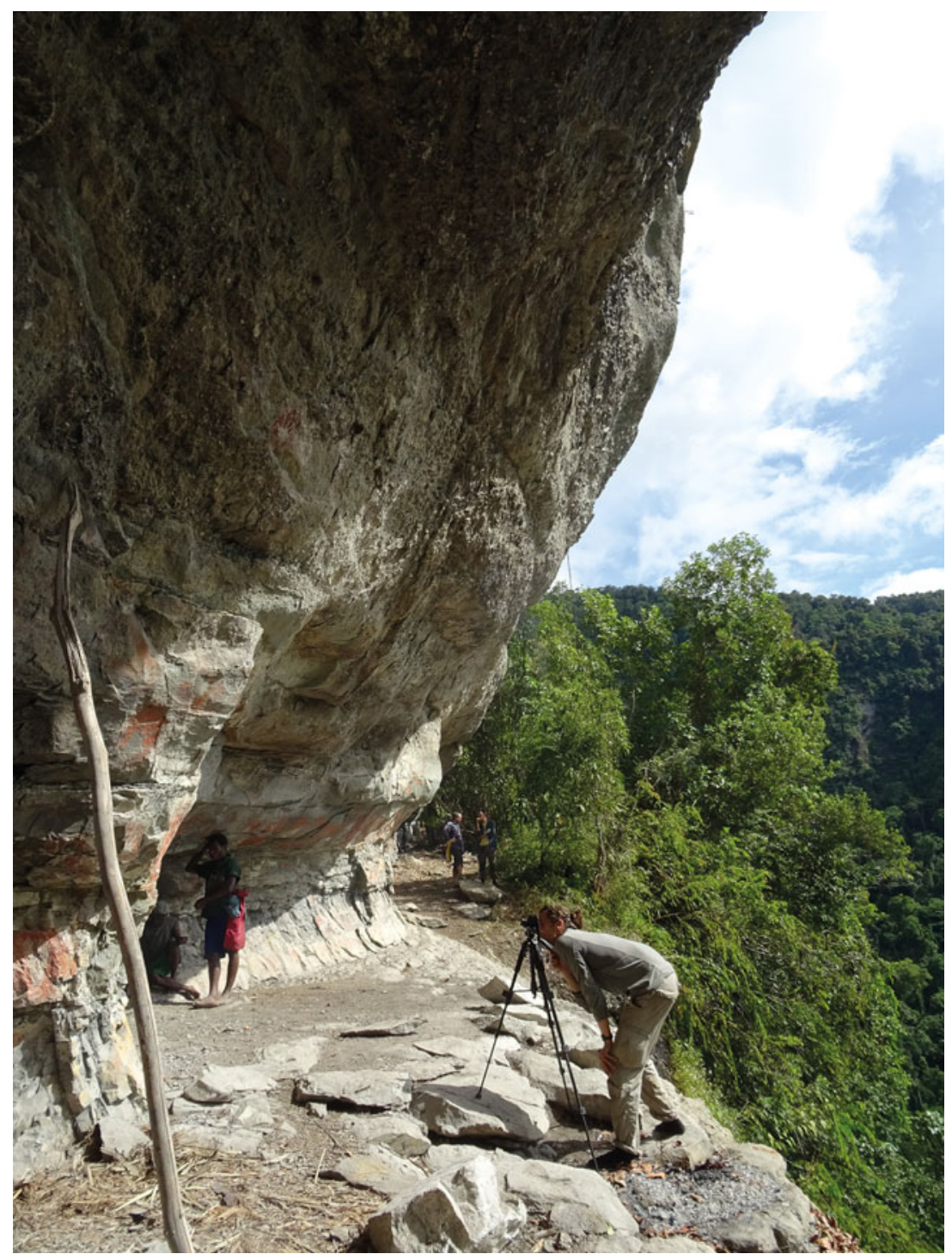

Figure 7. Recording rock art at Pundimbung rock-shelter, 2018. (Photograph: Hubert Forestier, Papuan Past Project.) region, cassowary eggshell microstructural analysis has revealed the possibility of avian husbandry to be as early as the Late Pleistocene with a possibility of people collecting eggs to hatch and rear cassowary chicks (Douglass et al. 2021). They have also suggested that New Guinea Highlanders practised the earliest known occurrence of avian husbandry which possibly predates Auwim. While we understand that until recently cassowaries were used for trade, it was not disclosed at the time of the fieldwork whether the cassowary in Figure 1 is being reared for an income, but we believe it may be used for consumption and tool production, given that contemporary Auwim described how daggers are manufactured from cassowary tibiotarsus.

Ethnographic reports suggest that Auwim cassowary bone daggers are made in four main stages.
These include (i) hunting; (ii) consumption; (iii) ceremonial cleaning; and (iv) ceremonial drying/smoking (Tsang 2018, 16). Hunting for cassowaries is not only for food (subsistence) and artefactual material, but also has a celebration aspect when hunting is successful. After they consume the meat as protein, they soak the tibia in a nearby creek to get rid of the remaining flesh off the bones via various river creatures (e.g. fish or crabs). The tibia remains in the creek for about two weeks to a month, and then it is removed from the water. The tibiotarsus is then sharpened from the top, at its grip area down to its end (the proximal edge/point) with a bush knife or any other sharp iron tool (prehistorically, their ancestors used a stone axe). It is mentioned that the edge of the tibia has to be very sharp to penetrate the skin or any object with no difficulty. Finally, once it 

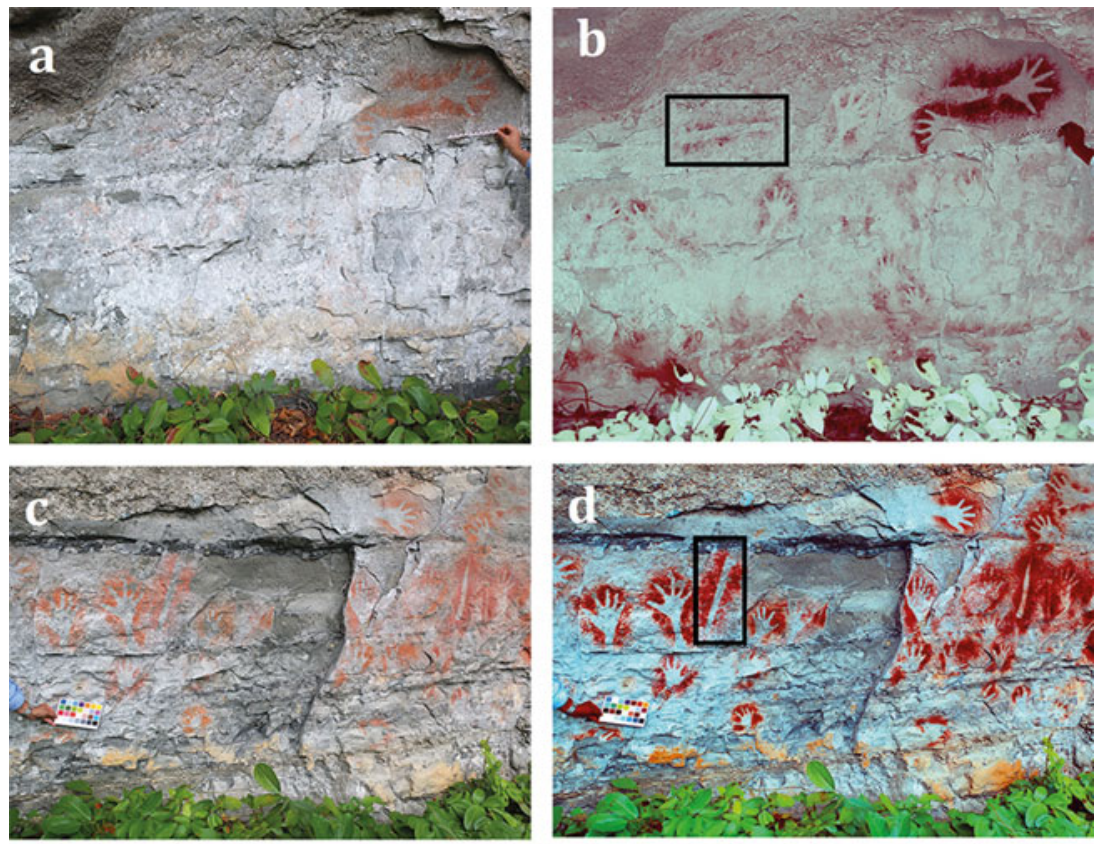

Figure 8. Seven bone daggers recorded in 2018 at Pundimbung rock-shelter. Bone daggers that are not clearly visible are highlighted in black rectangles for clarity. D-Stretch $(b, d, f$, and $h$ colour filters: yre, lrd, yuv, labi, respectively). (Original photographs: William Pleiber, Papuan Past Project; enhancement by Roxanne Tsang.)
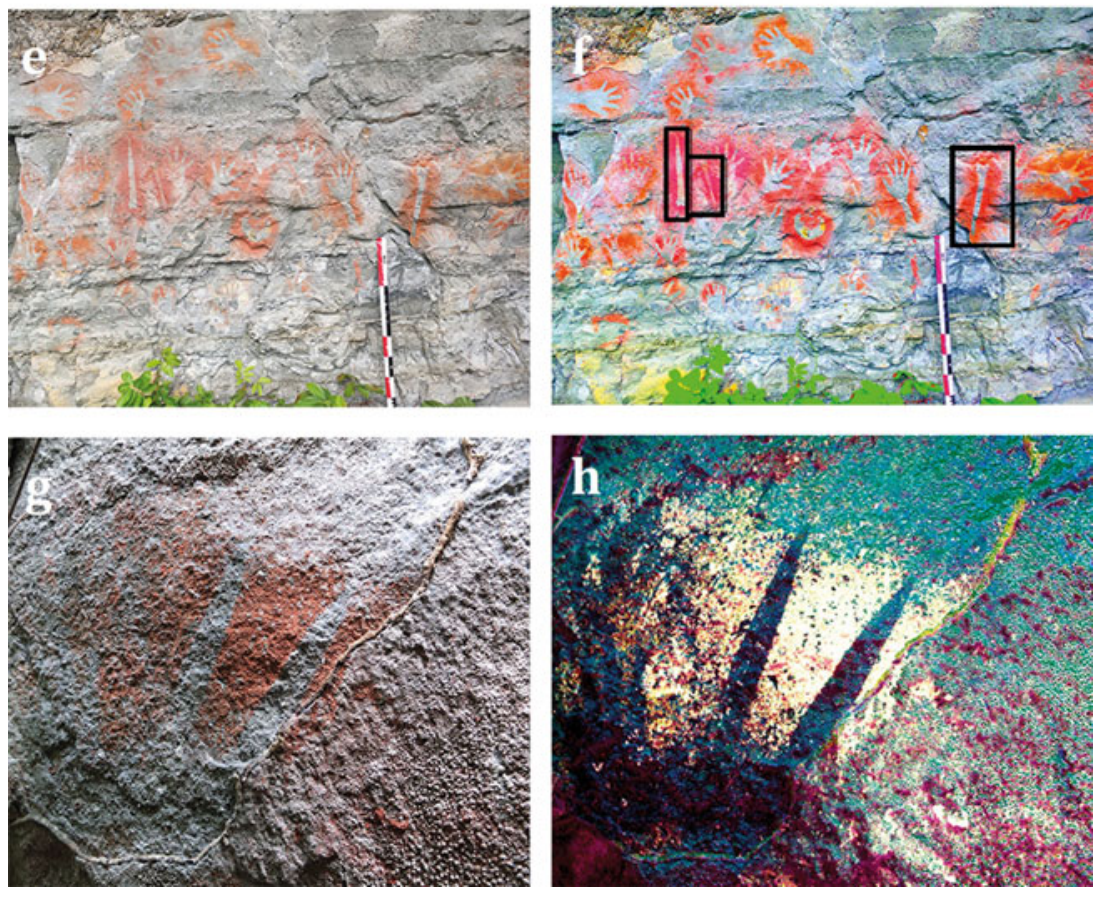

is sharpened, it is smoked and dried over the fire. After that, it is ready to be used for either hunting, warfare and/or as a self-protection weapon (Tsang 2018). This long process highlights the significance of the cassowary and its bones in society today and perhaps prehistorically.

Taken together, the identification of more bone daggers since 1987 and associated ethnography suggest further ideas behind events relating to cassowaries. Once a bone dagger object has been stencilled, it signifies the process from hunting (capturing chicks for husbandry) to consumption, ceremonial and tribal affairs, thus suggesting its cultural significance, relationship and/or connection people have between their landscape and resources, and socio-cultural life. The bone dagger stencil reflects the history of the cassowary from origin narrative to hunted species for food, as well as aspects of the ceremony, the making of important objects from its bones and then the very act of stencilling itself. 

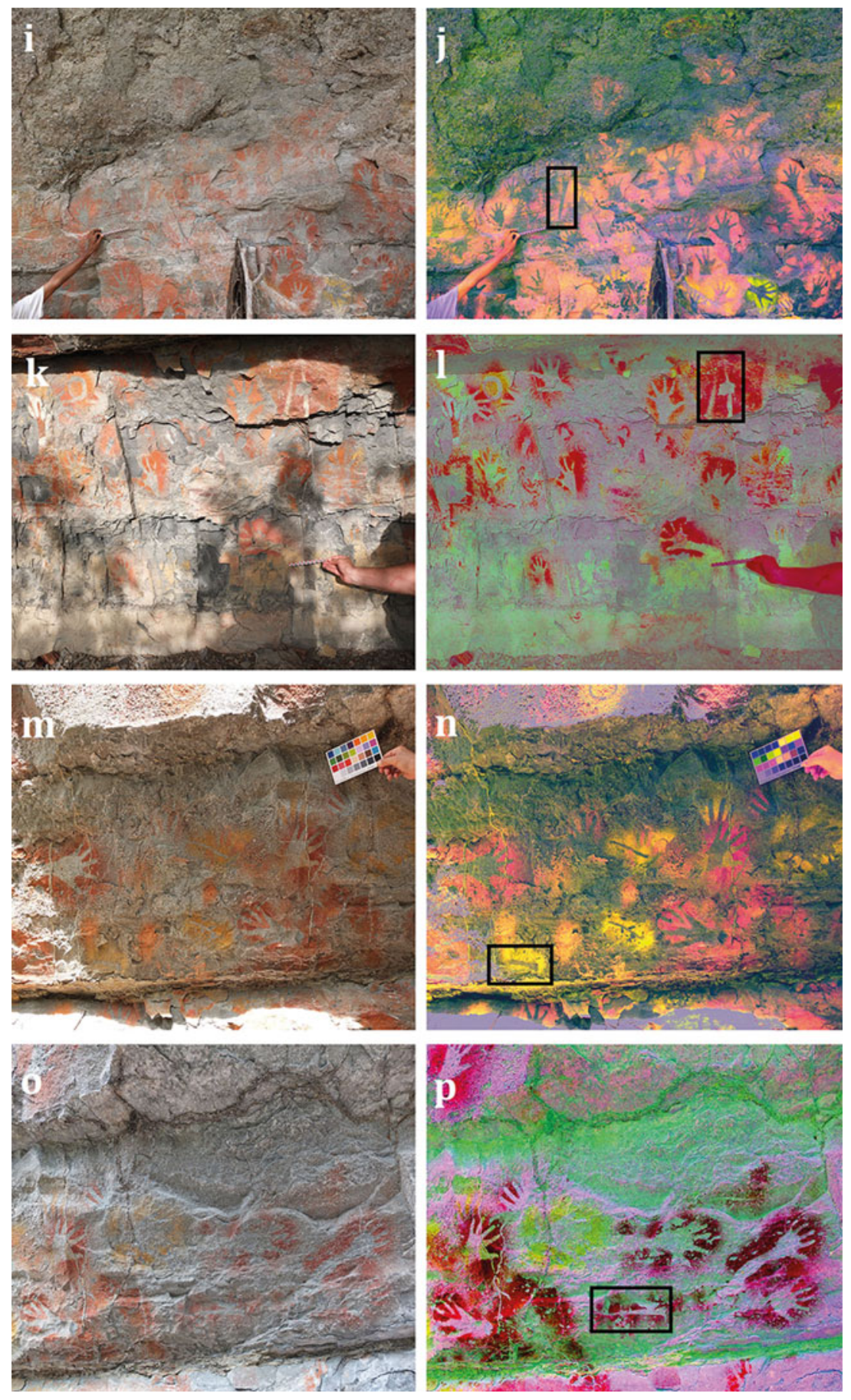

Figure 9. Five other bone daggers recorded in 2018 at Pundimbung rock-shelter. Bone daggers that are not clearly visible are highlighted in black rectangles for clarity. D-Stretch $(j, l, n$, and $p$ colour filters: $y x x$, lre, $y b k$, and $c r g b$, respectively). (Original photographs: William Pleiber, Papuan Past Project; enhancement by Roxanne Tsang.)

\section{Discussion}

Because ethnographic data have long played a significant role in interpreting Casuarius in New Guinea, we focus our discussion here on narratives around cassowary and their bone dagger stencils. The cassowary narrative and brief ethnographic account of its bone daggers provide a baseline approach about local perceptions of the species, associated portable ornament (or artefact) and an examination of the importance of stencilling in the Auwim region.

While we still lack chronological evidence of stencilling cassowary bone daggers in Auwim, we know from the nearby montane sites of Nombe and Kiowa, among others, that modern humans 
Figure 10. A cassowary bone dagger stencil at Pundimbung rock-shelter in 2018 (Photograph: Hubert Forestier, Papuan Past Project.)

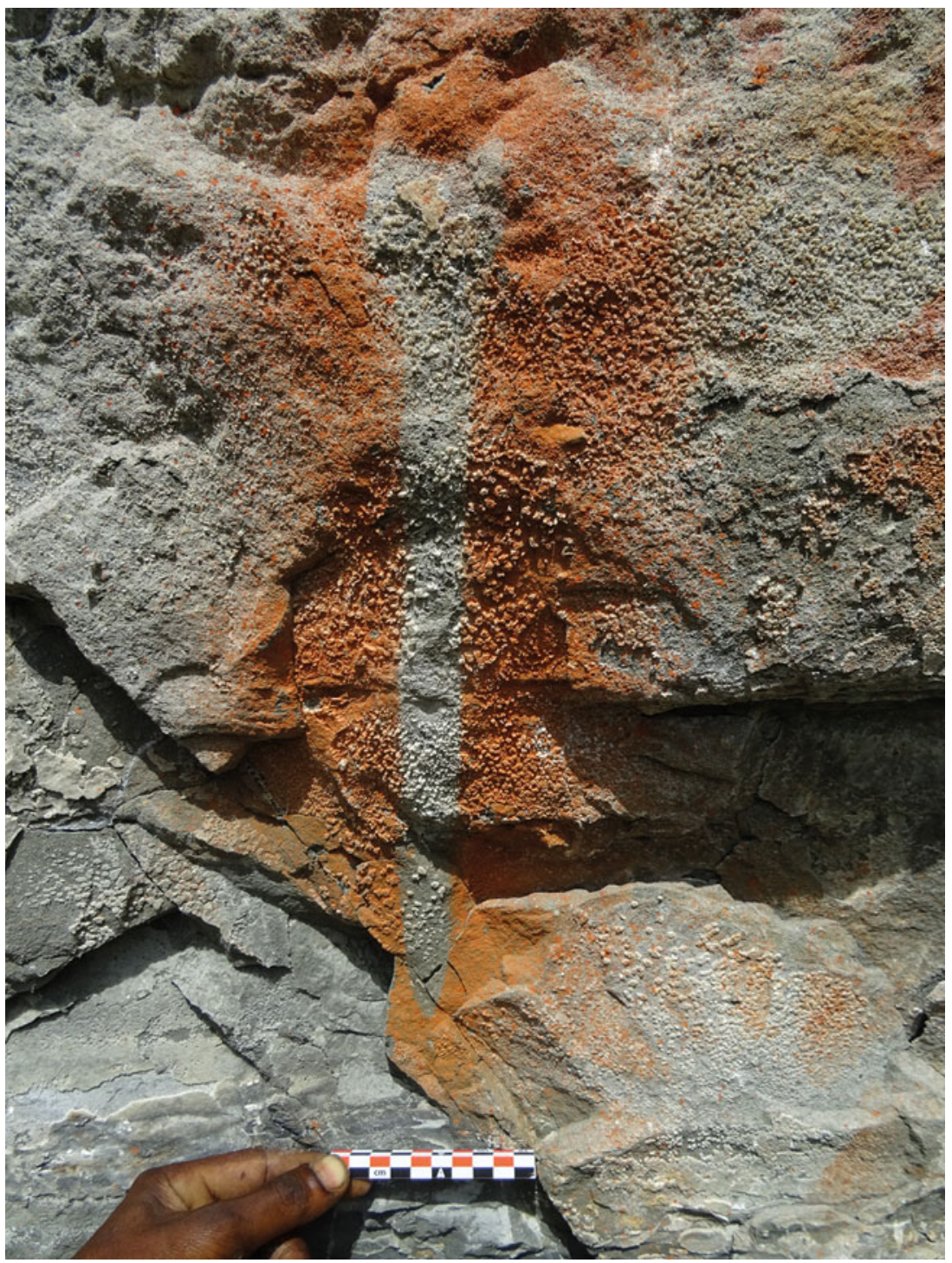

were utilizing the species, as is evident from cassowary bones and eggshell remains dated to 26,000 and 9000 years ago, respectively (Denham \& Mountain 2016; Gaffney et al. 2021; Mountain 1991), reflecting the long-term utilization of cassowaries in the past up to today. There is also a possibility of its tibiotarsus and other body-parts being worked into tools, as awls have been recovered from these sites (Mountain 1991; White 1972). These worked bones could be a Late Holocene innovation; however, thorough research into these tools should shed more light on them. As bone daggers function differently from culture to culture throughout PNG, we are confident that in East Sepik the importance of the species featuring in creation narratives, male hunting ability and rituals (Dominy et al. 2018; Newton 1989) highlights the significance of the species ornament when stencilling. We speculate on its stencilled importance by highlighting that cassowaries are about 'reproduction' where narratives or 'storied notions' (i.e. local narratives from contemporary communities) are generated through time. This means that cassowary narratives are produced as Auwim people hunt, kill, consume or rear, recycle (manufacture into cassowary objects) and eventually stencil their objects. Three aspects from Auwim local knowledge together with other examples across PNG about cassowaries can be woven together to explore the idea that 'cassowaries are about reproduction' and hence, stencilling could have represented the history of the animal in the Auwim region.

Cassowaries preserve the natural resource environment and cultural lives of the past and present people. For instance, ecologically, they are 


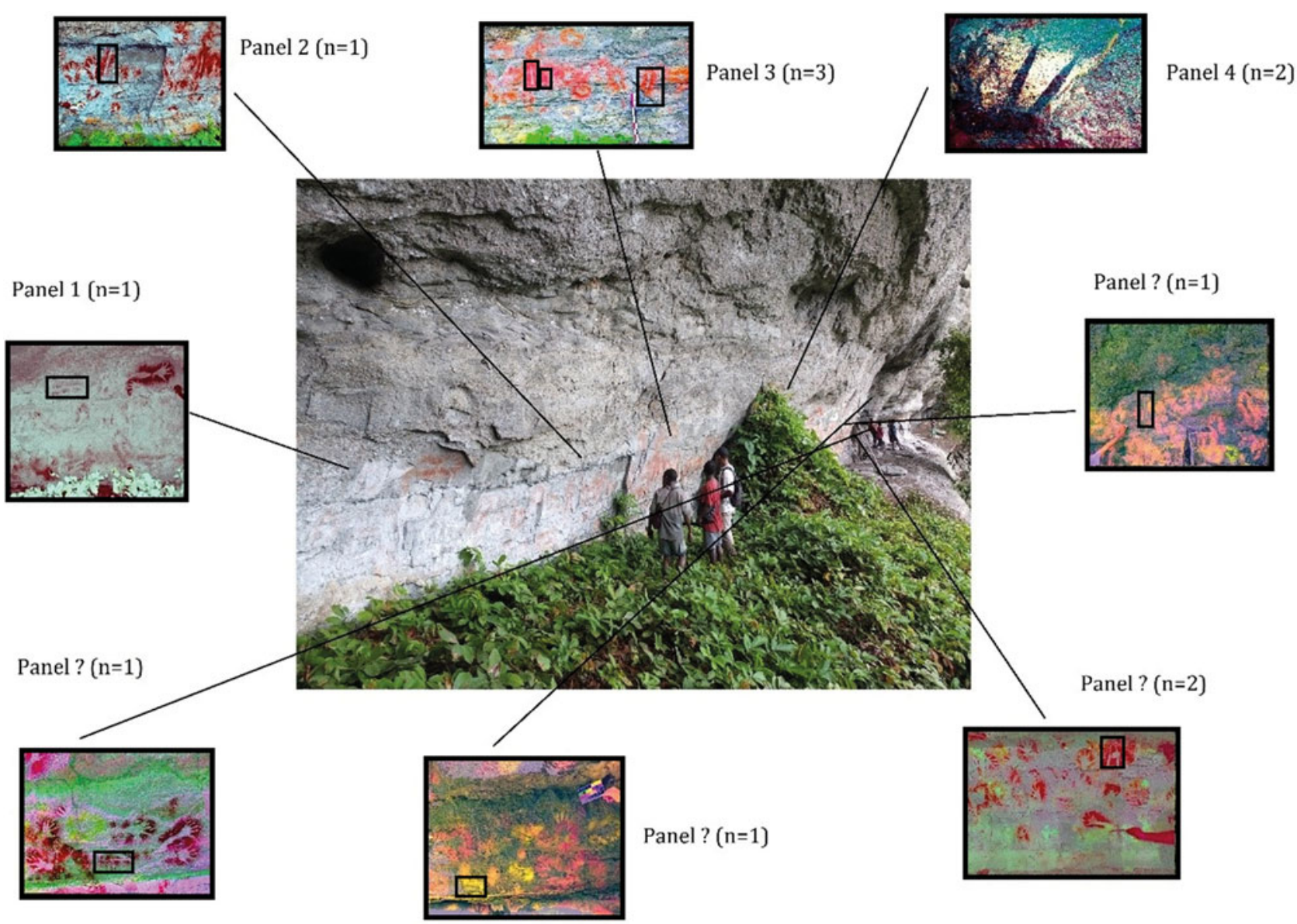

Figure 11. Preliminary approximate panel numbers and location of 12 bone dagger stencils at Pundimbung rock-shelter as of 2021 identification. (Original photograph: William Pleiber, Papuan Past Project 2018; adaption by Roxanne Tsang.)

renowned for their natural behaviour of maintaining the forest through seed dispersal. In this way, they sustain the forest by redistributing seeds and nuts under the canopy (e.g. Mack 1995). In Auwim, traditional-ecological knowledge illustrates that their 'fall to being flightless birds' allows other birds enough space to live and thrive. On Goodenough Island, cassowary stone narratives are associated with scarcity of food between husband and wife. For the Karam, their rules governing hunting restricts only two persons to hunt, which is also linked with either the flourishing or reduction of taro among other cultivated food. In contrast, cassowary was once a flightless bird in Auwim, whereas it is not a bird in Mianmin (Gardner 1984) and the Karam as they are cross-cousins (Bulmer 1967), while also creator beings in other parts of East Sepik (Newton 1989). These examples across PNG show varying 'stories' often relating to cassowaries and commonly linked to themes of people, food and ritual. Etiologically, they are seen as creator beings, such as in New Britain and East Sepik (Lattas 1989; Newton 1989). Further deliberate examples of such relationships between subsistence and ritual objects (connecting people with ritual and seascape/ landscapes worlds) can be seen from the Torres Strait Islands of Australia from both historical ethnographic records and archaeological remains of dugong mounds (McNiven \& Feldman 2003).

Ritualistically, cassowaries help men to reproduce cycles of hunting, tool production, initiation and homicide or 'payback'. The bone dagger motifs also immortalize the object and/or the event that had taken place using the bone dagger. More specifically, by stencilling, the homicide events in which actual bone daggers were used are remembered (see Hayward et al. 2018). The cassowary bone dagger motif thus communicates a story or message of the events that led to the object being carved into a weapon, the time it was hunted, processed and consumed, if the weapon had gone through cleansing and smoking ceremonies, and if indeed it was used 


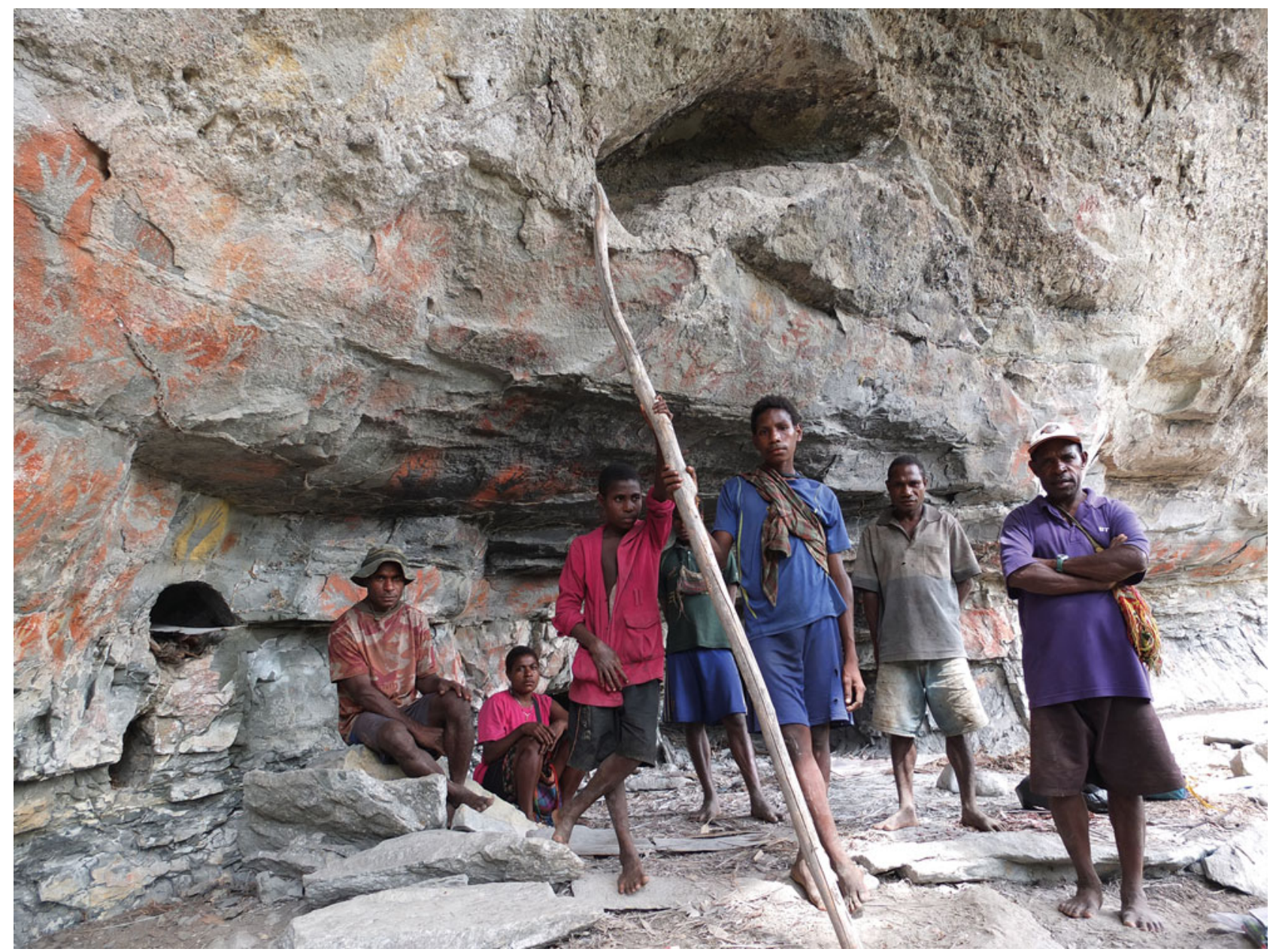

Figure 12. Sebastien Katuk (in purple T-shirt) with other Auwim members at Pundimbung rock-shelter in 2018. (Photograph: William Pleiber, Papuan Past Project.)

in a homicide event. The rock-art image may represent all these events for the local audience (i.e. Auwim) within their territorial boundary (i.e. clan groups). It is also apparent that the bone dagger motifs could directly link with the hand stencils, and therefore those clan members of the Pundimbung site who made and used the bone daggers for utilitarian purposes besides initiation ceremonies as represented in the artefacts (e.g. Mamkas, or stone flakes used for cutting initiate's skin) at Pundimbung rock-shelter (Gabriel \& Gorecki 2014; Gorecki \& Jones 1987a,b). For homicide or 'payback', there are some examples in the context of recent inter-ethnic conflicts and cassowary bone daggers were even used as a peace-making ornament (Roscoe \& Telban 2004, 105-7), including selfprotection weapon today (Tsang 2018). This suggests multi-purpose objects owing to time, place and event that can be replicated easily.
Furthermore, at Pundimbung, segregated chambers have specific functions such as those for boys' initiations/ceremonies, as well as chambers for women, girls and uninitiated boys (Gabriel \& Gorecki 2014; Gorecki \& Jones 1987a,b). All panels contain rock art, although 84 per cent of the bone daggers are sporadically located across two main sections of Pundimbung rock-shelter (Figs. 8-9 \& 11), reflecting designated sections specifically for these daggers which, in turn, could relate to boys' initiations. Equally, for the Abelam (about $143 \mathrm{~km}$ north of Auwim), their three-dimensional paintings of ceremonial houses are linked with aspects of ancestral beings in which mother cassowary is one. Specific motifs point to the sequence of initiation ceremonies that also describe people's initiation movement from a primary forest environment to the ritual centre located in the village (Kaufmann 2010, 10). In West Papua, highly valued objects were stencilled on the 
cliffs/cave walls including bronze axes that were exotic trade objects from Vietnam imported in exchange for the bird of paradise plumes (Swadling et al. 2019). It is also known that people around the Bird's Head area would chip off pieces of old bronzes and wear them as talismans. According to local narratives about rock art, the practice of stencilling valuable objects may have involved gendered magic.

While acknowledging that specific motif stencils may have played different roles over time, we argue that bone dagger stencils represent the material history of the cassowary and its world as a direct manifestation of the represented species. The $C$. unappendiculatus bone dagger stencils represent different events signifying the use and role of cassowaries in clan identities (as also do hand stencils at a more individual level) and resource-landscape use in the Auwim community. Therefore, the bone dagger stencil imagery itself plays an important role in contextualizing narratives as represented elsewhere in Sepik art (e.g. Kauffman 2010). Like the Karam with their cassowary-hunting regulations (Bulmer 1967), the Auwim also have a set procedure leading up to the making of the dagger ornament. Thus, we argue that these bone dagger stencils in Auwim are more than just stencils (e.g. see May et al. 2020) and represent an event at a point in time of peoples' lives. The stencils encapsulate narratives of the Auwim people's interactive relationship with their landscape and resources (e.g. cassowary used as a protein source/ acquisition) and their socio-cultural lives (e.g. traditional belief systems). They are storied artefacts which remind Auwim people of their relationship to the cassowary, the origin narratives and their surrounding landscape, as well as their cosmological beliefs and cultural obligations for tribal warfare, among others. Thus, this material history of the bone dagger once stencilled can have its own characteristics which could involve its strength, vitality, and ferocity of cassowaries making its way into the bone daggers. These characteristics allowed these objects to inflict wounds or kill people during conflicts and skirmishes where, through time, these narratives are often reproduced.

In 2018, RT discussed the community's contemporary social interactions with pre-existing rock-art sites or images with local community members Mark, Peter and co-author SK. SK responded that they still interact with these rock-art sites, but they only go to visit them and come back to the village (sometimes they visit, sleep or stop over while hunting and come back to the village). He also stated that they can create rock art when they go there; however, it is only if there is a cultural purpose for it (and if the timing is right) and the current community have never done so for Pundimbung. This suggests that making rock art is still a local tradition, but not done regularly, rather only for special and/or ceremonial occasions (for the former, see e.g. Tsang et al. 2021).

For the bone daggers, stencilling may have been a prerequisite for male initiation and or perhaps relating to homicide (Gabriel \& Gorecki 2014). Similarly, in the Highlands of PNG, tallies are produced to count the number of foes killed. In West Papua, people also produce stencils of valuable and possibly 'magical' objects. Rock art in East Sepik and broader PNG is a complex phenomenon with further research needed. We have, however, highlighted that contemporary narratives remain crucial for a more nuanced understanding.

\section{Conclusion}

Our new ethnographic information relating to cassowaries, the process of bone dagger ornamentation, and identification of new bone dagger imagery from Auwim, Upper Karawari-Arafundi region in East Sepik, broadens our understanding of how Papua New Guineans link their cultural material objects with rock-art creation, their environment, socio-cultural life and cosmology. Our study has revealed that different events associated with cassowaries appear to have different narratives. We propose that the cultural beliefs and practical uses of cassowaries are unique, and this is revealed in Auwim rock art. Cassowary bone daggers in the rock art of Auwim represent significant events, a 'storied notion' of people's engagement with the species in the landscape and rituals leading up to the stencilling of the portable weapon or object.

\section{Acknowledgements}

We are grateful to the Auwim community for sharing their traditional knowledge and hospitality in 2018. Fieldwork was funded by a National Geographic Society Grant (HJ-156R-17 to F-XR) for the project 'Prehistory of the Karawari region in East Sepik, Papua New Guinea' (2018). We extend our sincere gratitude to the broader funders and collaborators of the Papuan Past Project, namely the French National Research Agency, the French Ministry for Europe and Foreign Affairs (France), the French Embassy in Papua New Guinea, University of Papua New Guinea-and particularly the Strand of Anthropology, Sociology and Archaeology of the School of Humanities and Social Sciences, the Papua New Guinea National Research Institute and Papua New Guinea National Museum and Art Gallery. For fieldwork 
assistants, we thank Professor Hubert Forestier, Dr Sébastien Plutniak, William Pleiber and Jason Kariwiga. Dr Robin Hide (Australian National University), Dylan Gaffney (Cambridge University) and Dr Andrew Mack (Pennsylvania State University, Altoona) are thanked for email discussions and for sharing various references. We are also grateful to Dr Paul Jim Roscoe (University of Maine) and Dr Nathaniel J. Dominy (Dartmouth College) for permission to adapt their original map in Figure 3. Dr Andrea Jalandoni (Griffith University) is thanked for adapting Figures 3 and 8 . We are also grateful to the two anonymous reviewers for their helpful comments and generous ideas to improve this paper further. Griffith University is thanked for supporting RT's PhD research and this current paper.

Roxanne Tsang School of Humanities, Languages and Social Science $\mathcal{E}$ PERAHU Griffith Centre for Social and Cultural Research Griffith University Gold Coast Campus, QLD 4222 Australia Email: roxanne.tsang@griffithuni.edu.au

Sebastien Katuk Auwim Village Upper Karawari-Arafundi Region East Sepik Province Papua New Guinea

Sally K. May PERAHU Griffith Centre for Social and Cultural Research Griffith University Gold Coast Campus, QLD 4222 Australia Email: s.may@griffith.edu.au

Paul S.C. Taçon PERAHU Griffith Centre for Social and Cultural Research

Griffith University Gold Coast Campus, QLD 4222 Australia

Email:p.tacon@griffith.edu.au

François-Xavier Ricaut Laboratoire Évolution et Diversité Biologique (EDB Science UMR 5174) Université de Toulouse Midi-Pyrénées CNRS, IRD, UPS

Toulouse France Email: francois-xavier.ricaut@univ-tlse3.fr
Matthew G. Leavesley Archaeology School of Humanities and Social Science University of Papua New Guinea Port Moresby Papua New Guinea College of Arts, Society \& Education James Cook University Cairns, QLD 4811 Australia Email: matthew.leavesley@gmail.com

\section{References}

Allen, J., 2017. Excavations on Motupore Island (Vol.1). Dunedin: Department of Anthropology \& Archaeology, University of Otago.

Aplin, K., 1981. Kamapuk fauna: A late Holocene Vertebrate Faunal Sequence from the Western Highlands District, Papua New Guinea with Implications for Palaeoecology and Archaeology. Unpublished BA (Hons) thesis, Australian National University.

Arifin, K. \& P. Delanghe, 2004. Rock Art in West Papua. Paris: UNESCO.

Bahn, P.G. 1998. The Cambridge Illustrated History of Prehistoric Art. Cambridge: Cambridge University Press.

Basiaco, A., C. Urwin \& T. Manne, 2020. Worked bone and teeth from Orokolo Bay in the Papuan Gulf (Papua New Guinea). Australian Archaeology 86(3), 226-37.

Bulmer, R., 1967. Why is the cassowary not a bird? A problem of zoological taxonomy among the Karam of the New Guinea Highlands. Man 2(1), 5-25.

Bulmer, R., 1976. Selectivity in hunting and in disposal of animal bone by the Kalam of the New Guinea Highlands, in Problems in Economic and Social Archaeology, eds G.de G. Sieveking, I. Longworth \& K.E. Wilson. London: Duckworth, 169-86.

Bulmer, S., 1964. Radiocarbon dates from New Guinea. Journal of the Polynesian Society 73(3), 327-8.

Bulmer, S., 1966. The Prehistory of the New Guinea Highlands. Unpublished MA thesis, University of Auckland.

Bulmer, S., 1975. Settlement and economy in prehistoric Papua New Guinea. Journal de la Société des Océanistes 31, 7-75.

Bulmer, S., 1979. Archaeological Evidence of Prehistoric Faunal Change in Highland Papua New Guinea. Unpublished paper to Australian and New Zealand Association for the Advancement of Science Congress, Section 25A, Auckland, 1979.

Christiansen, O.A., 1975. Hunters and horticulturalists: A preliminary report of the 1972-4. Excavations in the Manim Valley, Papua New Guinea. Mankind 10(1), 24-36. 
Cranstone, B.A.L., 1971. The Tifalmin: a 'Neolithic' people in New Guinea. World Archaeology 3(2), 132-42.

Denham, T., 2016. Revisiting the past: Sue Bulmer's contribution to the archaeology of Papua New Guinea. Archaeology in Oceania 51, 5-10.

Denham, T. \& M.J. Mountain, 2016. Resolving some chronological problems at Nombe rock shelter in the highlands of Papua New Guinea. Archaeology in Oceania 51 (S1), 73-83.

Dominy, N.J., S.T. Mills, C.M. Yakacki, P.B. Roscoe \& R. D. Carpenter, 2018. New Guinea bone daggers were engineered to preserve social prestige. Royal Society Open Science 5(4), 172067.

Douglass, K., D. Gaffney, T.J. Feo, P. Bulathsinhala, L. M. Mack, M. Spitzer \& G.R. Summerhayes, 2021. Late Pleistocene/Early Holocene sites in the montane forests of New Guinea yield early record of cassowary hunting and egg harvesting. Proceedings of the National Academy of Sciences 118(40), e2100117118.

Edwards, E. \& N. Sullivan, 2008. Preliminary Report of the Cruz Mayor Rock Art Expedition to Papua New Guinea. An Explorers Club Flag 83 Expedition.

Egloff, B.J., 1970. The rock carvings and stone groups of Goodenough Bay, Papua. Archaeology \& Physical Anthropology in Oceania 5(2), 147-56.

Gabriel, J. \& P. Gorecki, 2014. The 'Karawari Caves Precinct' of the Sepik River Basin, Papua New Guinea. Cairns: Cairns Institute, James Cook University.

Gaffney, D., G.R. Summerhayes, S. Luu, J. Menzies, K. Douglass, M. Spitzer \& S. Bulmer, 2021. Small game hunting in montane rainforests: specialised capture and broad spectrum foraging in the Late Pleistocene to Holocene New Guinea Highlands. Quaternary Science Reviews (253), 106742.

Gardner, D.S., 1984. A note on the androgynous qualities of the cassowary: or why the Mianmin say it is not a bird. Oceania 55(2), 137-45.

Gorecki, P., \& R. Jones, 1987a. A New Rock Art Province in New Guinea. Canberra: Australian National University, Department of Prehistory, Research School of Pacific Studies.

Gorecki, P., \& R. Jones, 1987b. Rock Art in the Upper Arafundi and Upper Karawari Rivers, East Sepik Province. Canberra: Australian National University, Department of Prehistory, Research School of Pacific Studies.

Hayward, J.A., I.G. Johnston, S.K. May \& P.S.C. Taçon, 2018. Memorialization and the stencilled rock art of Mirarr Country, northern Australia. Cambridge Archaeological Journal 28(3), 361-78.

Herdt, G.H., 1981. Guardians of the Flute. New York (NY): McGraw-Hill.

Kaufmann, C., 2010. Changing role in shaping our understanding of Sepik Art (Part II). Pacific Arts n.s. 9(1), 5-14.

Ker, A., 1910. Papuan Fairy Tales. London: Macmillan.

Landtman, G., 1933. Ethnographic Collection from the Kiwai district of British New Guinea in the National Museum of Finland, Helsingfors (Helsinki): a descriptive survey of the material culture of the Kiwai people. Helsinki: Commission of the Antell Collection.

Lattas, A., 1989. Trickery and sacrifice: Tambarans and the appropriation of female reproductive powers in male initiation ceremonies in west New Britain. Man n.s. 24(3), 451-69.

Mack, A.L., 1995. Seed Dispersal by the Dwarf Cassowary, Casuarius bennetti, in Papua New Guinea. Unpublished PhD dissertation, University of Miami.

Majnep, I.S. \& R. Bulmer, 1977. Birds of My Kalam Country. Auckland/Oxford: Auckland University Press/ Oxford University Press.

May, S.K., L. Taylor, C. Frieman, et al. 2020. Survival, social cohesion and rock art: the painted hands of Western Arnhem Land, Australia. Cambridge Archaeological Journal 30(3), 491-510.

McNiven, I.J. \& R. Feldman, 2003. Ritually orchestrated seascapes: hunting magic and dugong bone mounds in Torres Strait, NE Australia. Cambridge Archaeological Journal 13(2), 169-94.

Mountain, M.-J. 1991. Highland New Guinea Hunter-Gatherers: The Evidence of Nombe Rockshelter, Simbu with Emphasis on the Pleistocene. Unpublished PhD thesis, Australian National University.

Newton, D., 1989. Mother Cassowary's bones: daggers of the East Sepik Province, Papua New Guinea. Metropolitan Museum Journal 24, 305-25.

O'Connor, S., K. Aplin, J. Pasveer \& G. Hope, 2005. Liang Nabulei Lisa: a late Pleistocene and Holocene sequence from the Aru Islands, in The Archaeology of the Aru Islands, Eastern Indonesia, eds S. O'Connor, M. Spriggs \& P. Veth. (Terra Australis 22.) Canberra: ANU Press, 125-61.

O'Connor, S., A. Barham, K. Aplin, K. Dobney, A. Fairbairn \& M. Richards, 2011. The power of paradigms: examining the evidential basis for early to mid-Holocene pigs and pottery in Melanesia. Journal of Pacific Archaeology 2(2), 1-25.

Pangau-Adam, M., M. Mühlenberg \& M. Waltert, 2015. Rainforest disturbance affects population density of the northern cassowary Casuarius unappendiculatus in Papua, Indonesia. Oryx 49(4), 735-42.

Pasveer, J.M., 2004. The Djief Hunter: 26,000 Years of Rainforest Exploitation on the Bird's Head of Papua, Indonesia. (Modern Quaternary Research in Southeast Asia 17.) Boca Raton (FL): CRC Press.

Pouwer, J., 1991. The willed and the wild: the Kalam cassowary revisited. Oceania 25, 17-22.

Rhoads, J.W., 1980. Through a Glass Darkly: Present and Past Land-use Systems of Papuan Sago Palm Users. PhD thesis, Australian National University.

Röder, J., 1959. Felsbilder und Vorgeschichte des MacCluer-Golfes West-Neuguinea. Darmstadt: L.C. Wittich.

Roscoe, P. \& B. Telban, 2004. The people of the Lower Arafundi: tropical foragers of the New Guinea rainforest. Ethnology 43(2), 93-115.

Specht, J., R. Torrence \& K. Mulvaney, 2021. Petroglyphs and place: complex histories at four sites in New Britain. Archaeology in Oceania 56(3), 196-228. 
Steadman, D.W., 2006. Extinction and Biogeography of Tropical Pacific Birds. Chicago (IL): University of Chicago Press.

Strong, W.M., 1923. Rock paintings from Central District, Papua (British New Guinea). Man 23(119), 185-6.

Swadling, P., R. Wagner \& B. Laba, 2019. Plumes From Paradise. Sydney: Sydney University Press.

Taçon, P.S.C. \& C. Chippindale, 1998. An archaeology of rockart through informed methods and formal methods, in The Archaeology of Rock-Art, eds C. Chippindale \& P.S.C. Taçon. Cambridge: Cambridge University Press, 1-10.

Taçon, P.S.C., M. Langley, S.K. May, R. Lamilami, W. Brenan \& D. Guse, 2010. Ancient bird stencils discovered in Arnhem Land, Northern Territory, Australia. Antiquity 84, 416-27.

Terrell, J. \& R.L. Welsch, 1990. Trade networks, areal integration; and diversity along the north coast of New Guinea. Asian Perspectives 29(2), 155-65.

Tsang, R. 2018. Field report on ethno-archaeology survey of Awim rock art, Karawari/Arafundi, Papua New Guinea to Papuan Past Project, 2018. Unpublished report. Port Moresby: Papua New Guinea National Museum and Art Gallery.

Tsang, R., L.M. Brady, S. Katuk, P.S.C. Taçon, F.-X. Ricaut \& M.G. Leavesley, 2021. Agency, affect and archaeologists: transforming place with rock art in Auwim, Upper Karawari-Arafundi region, East Sepik, Papua New Guinea. Rock Art Research 38(2), 183-94.

Tsang, R., W. Pleiber, J. Kariwiga, et al. 2020. Rock art and long-distance prehistoric exchange behavior: a case study from Auwim, East Sepik, Papua New Guinea. Journal of Island and Coastal Archaeology. DOI: 10.1080/15564894.2020.1834472

Vanderwal, R.L., 1973. Prehistoric studies in Coastal Papua. Unpublished $\mathrm{PhD}$ thesis, Australian National University.

White, J.P., 1972. Ol Tumbuna: Archaeological excavations in the Eastern Central Highlands, Papua New Guinea. (Terra Australis 2.) Canberra: ANU Press.

Williams, F.E. 1940. Drama of Orokolo: The Social and Ceremonial Life of Elema. Oxford: Oxford University Press.

\section{Author biographies}

Roxanne Tsang is a $\mathrm{PhD}$ candidate with the School of Humanities, Languages and Social Science, and the Place,
Evolution and Rock Art Heritage Unit at Griffith University, Queensland, Australia. Her current research focuses on the ethnoarchaeology of rock art, particularly, hands and material culture object stencils from East Sepik, Papua New Guinea.

Sebastien Katuk is a Senior Traditional Owner and Community leader of Auwim village in the Upper Karawari-Arafundi region of East Sepik Province in Papua New Guinea. He has vast experience working collaboratively with both Papua New Guineans and international researchers about local associated knowledge of both their current and past cultural practices.

Sally K. May is a Principal Research Fellow with the Place, Evolution and Rock Art Heritage Unit at Griffith University. As an archaeologist and anthropologist, her research focuses on relationships between people, landscapes, material culture and imagery, with inspiration drawn primarily from fieldwork in northern Australia.

Paul S.C. Taçon FAHA, FSA is a Distinguished Professor, a former ARC Australian Laureate Fellow (2016-2021), Chair in Rock Art Research and Director of Griffith University's Place, Evolution and Rock Art Heritage Unit. Archaeological and ethnographic fieldwork since 1980 has led to over 300 academic publications on rock art, cultural heritage and human evolution.

François-Xavier Ricaut is a Senior Researcher at The National Center for Scientific Research (CNRS) in the Department of Evolution and Biological Diversity at the University of Toulouse, France. As a biological anthropologist, his research investigates the ecological, cultural and evolutionary processes which structure the biological diversity of human populations, especially in the IndoPacific region, using archaeological remains and biological markers

Matthew G. Leavesley is a Senior Lecturer in Archaeology at the University of Papua New Guinea, Port Moresby. Research interests revolve around notions of prehistoric human adaptation(s) to depauperate/marginal environments with particular reference to case studies in Papua New Guinea. 